\title{
Bilateral, anterior stromal ring opacity of the cornea
}

Gerrit R J Melles, Johan P de Séra, Cathrien A Eggink, Johan R M Cruysberg, Perry S Binder

\begin{abstract}
Aims/background-To describe a bilateral, mid peripheral, ring-shaped corneal opacity, not resembling any known corneal degeneration, dystrophy, or other disorder, and occurring without ocular or systemic disease.

Methods-Ophthalmic examination, haematological screening, and ultrasound biomicroscopy.

Results-A 25 year old man showed greywhite, granular opacities in both corneas, with an $8 \mathrm{~mm}$ diameter ring configuration, and a V-shaped distribution in the anterior stroma. The surrounding corneal stroma was clear, and the tear film, the epithelium and its basement membrane, Descemet's membrane, and the endothelium were normal. Evidence of systemic disease was not found. Family members did not show corneal abnormalities. Conclusion-A bilateral corneal ring opacity may occur in healthy, asymptomatic, young people. These corneal rings may result from depositions of unknown origin, or possibly a rare corneal dystrophy. (Br f Ophthalmol 1998;82:522-525)
\end{abstract}

In the past three decades, a ring-shaped opacity in the mid peripheral corneal stroma has been described in a total of six patients. ${ }^{1-5}$ In 1963, Ascher reported ${ }^{1}$ the occurrence of a bilateral, grey-white ring in the mid peripheral cornea of a 39 year old man with recurrent, unilateral iritis of unknown cause. The ring was sharply demarcated, about $7 \mathrm{~mm}$ in diameter, and located in the superficial corneal stroma.

Bron described ${ }^{2}$ a similar corneal ring opacity in both eyes of a 59 year old white male and a 66 year old white female, who presented with unilateral marginal infiltrates. In both patients, the opacities were wedge-shaped with a dense base over Descemet's membrane and a faint apex underneath Bowman's layer, and located in the mid or far corneal periphery. Rieger documented $^{3}$ a unilateral, annular opacity in the right cornea of a 65 year old man. A perfect ring was located in the mid periphery and extended posteriorly to about two thirds of corneal thickness. Bopp and Laqua described ${ }^{4}$ a bilateral, ring-shaped opacity in a 65 year old man and an 80 year old woman. The rings were 4-5 $\mathrm{mm}$ and $7-8 \mathrm{~mm}$ in diameter, and extended half way down the stroma.

Depending on concomitant ocular findings, the occurrence of this corneal ring opacity has been speculated to result from an immunological reaction after ocular inflammation, or degenerative changes with advancing age. In the current report, we describe the presence of a bilateral, ring-shaped, mid peripheral corneal opacification as an isolated finding in a young, healthy patient, who did not have a history of ocular inflammation.

\section{Patient and methods}

A 25 year old man with a bilateral, ring-shaped corneal opacity of unknown origin underwent complete ophthalmic examination, as well as haematological screening for known metabolic disorders, and ultrasound biomicroscopy at 50 $\mathrm{MHz}$ (Ultrasound Biomicroscope, Humphrey) of his corneas.

\section{Results}

In 1981, at the age of 11, a Mediterranean man was first examined by us, after a bullet from a small bore rifle had hit his right eye. A hyphaema and a vitreous haemorrhage had developed, which cleared in 3 weeks. At that time, funduscopy revealed the presence of five attached retinal breaks in the temporal quadrant, which were treated with argon laser photocoagulation.

From 1981 to 1993 , he was seen at yearly intervals by his own ophthalmologist. During this period, corneal abnormalities were not observed. In 1993, he was examined by us for complaints of floaters, which were attributed to a posterior vitreous detachment in the right eye. In 1995, he was referred to us because both corneas showed a faint, grey-white, granular deposition in a perfect continuous circle, with a diameter of approximately 8.0 $\mathrm{mm}$ and a width of about $1 / 3 \mathrm{~mm}$ (Fig 1A-D). From anterior to posterior, the opacity had a V-shaped configuration; the lower end of the V extended into the mid stroma, sharply demarcated from the surrounding, clear corneal stroma (Fig 1E). The tear film, the epithelium, and the endothelial layer were unremarkable; the ocular surface did not stain with fluorescein, the epithelium had normal thickness, basement membrane abnormalities were not seen, and specular microscopy showed a normal endothelial layer. The stroma did not show central thinning or other abnormalities. Both eyes were quiet. The other media were clear and, except for the areas treated with laser photocoagulation, the fundi were normal.

The uncorrected visual acuity was 1.0 in both eyes. Regular, smooth keratometry readings were $44.0 \times 43.5 \mathrm{D}$ in the right eye, and $43.0 \times 43.0 \mathrm{D}$ in the left eye. Corneal sensitivity measured with a cotton tip was normal. Gonioscopy showed no abnormalities of the
Accepted for publication 19 November 1997 

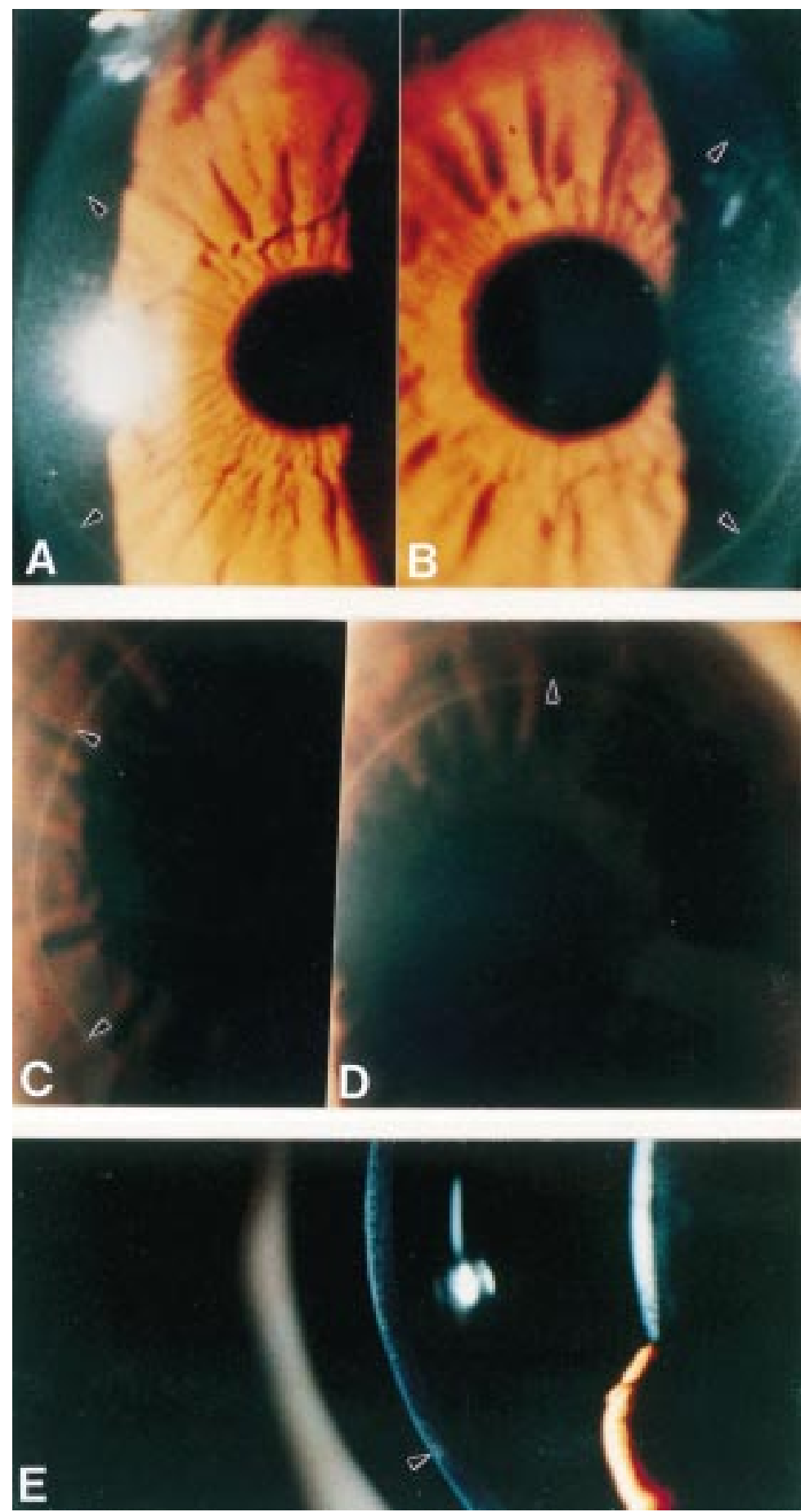

Figure 1 Slit lamp photographs of the right $(A$ and $C)$ and left eye ( $B$ and $D)$. Both corneas show a granular deposition with a configuration of a perfect ring, $8.0 \mathrm{~mm}$ in diameter- that is, sharply demarcated from the clear surrounding cornea. At higher magnification (E) the opacity appears to consist of a granular deposition with a V-shaped distribution in the anterior stroma.

anterior chamber angle. Our patient denied any previous ocular, orbital, or eyelid surgery, and, in particular, any type of excimer laser photoablation treatment. Except for the ocular trauma 14 years before, his medical history was unremarkable. He denied any symptoms of photophobia, pain, cold sores, or fever blisters. $\mathrm{He}$ had a profession in the paint producing industry, and worked with liquid trichlorethylene. $\mathrm{He}$ denied oral intake of vitamin $\mathrm{D}$, antihyperglycaemic, antiprotozoa (quinacine), antiarrhythmic, antirheumatic (gold, indomethacin), antiviral medication, iron, migraine (ergotamine), silver containing antibacterial, antipsychotic, antiangina (amiodarone), or antimalarial (chloroquine) drugs.

The haematological examination, serum copper and lipoprotein spectrum (VLDL, LDL, HDL, triglycerides, cholesterol, apolipoprotein I and II) were normal. Serological tests for syphilis (VDRL and TPHA), Lyme disease, and sarcoid (angiotensin converting enzyme and lysozyme) were negative. Urine analysis for mucopolysaccharides, amino acids, and organic acids (homogentisic acid) in the urine showed no abnormalities. With ultrasound biomicroscopy the corneal deposition could not be detected.

The patient's father was found to have a mild arcus senilis in both corneas, and his mother had bilateral crocodile shagreen. The 4 year old son of our patient showed no corneal abnormalities, and his 1 year old daughter did not permit ocular examination. The patient's brother was not available for examination.

\section{Discussion}

A mid peripheral ring opacity has been described in six elderly patients (Table 1). ${ }^{1-5}$ Three of these patients presented with unilateral marginal infiltrate or iritis. ${ }^{12}$ It was suggested that the rings resulted from a non-specific degeneration at an advanced age, or from a bilateral immunological reaction associated with unilateral ocular inflammation (Wessely ring). We observed a bilateral, mid peripheral ring opacity in a healthy patient as a coincidental finding during routine ocular examination. Because our patient was relatively young and had never suffered from ocular inflammation, the aetiology of the ring-shaped corneal opacity is currently undetermined.

In the cornea, six patterns of pathological responses thought to be attributed to corneal opacity have been described: immune response, deposition, proliferation, defects, fibrosis with vascularisation, and oedema with cysts. ${ }^{6}$ In our patient, there was no evidence of an addition or a loss of corneal tissue, oedema, or vascularisation so the corneal ring opacity may be classified best as an "immune response" or a "deposition".

The most common immunological reaction that leaves a stromal, ring-shaped opacity is the Wessely ring after herpetic keratitis. ${ }^{7}$ Such a stromal scar most often follows (recurrent attacks of) stromal oedema associated with herpetic keratitis. Autoimmune disorders may often be limited to the peripheral cornea. ${ }^{78}$ Humoral and cellular factors from the limbal area may react to agents present within the central cornea, which may result in accumulation of immune complexes and associated inflammation in the peripheral cornea. However, since our patient did not have a history of keratouveitis or any evidence of systemic vasculitis, an interstitial or autoimmune keratitis may be an unlikely explanation for the development of the observed corneal ring opacity. 
Table 1 Patient characteristics in reported cases with a mid peripheral corneal ring opacity

\begin{tabular}{|c|c|c|c|c|c|c|c|c|c|c|c|}
\hline Reported cases & $\begin{array}{l}\text { Patient age } \\
\text { at time of } \\
\text { diagnosis, } \\
\text { and sex }\end{array}$ & $\begin{array}{l}\text { Uni-or } \\
\text { bilateral }\end{array}$ & $\begin{array}{l}\text { Diameter } \\
\text { (and width) } \\
\text { of rings } \\
(\mathrm{mm})\end{array}$ & $\begin{array}{l}\text { Distribution } \\
\text { opacities }\end{array}$ & $\begin{array}{l}\text { Appearance } \\
\text { opacities }\end{array}$ & $\begin{array}{l}\text { Progression } \\
\text { opacities at } \\
\text { diagnosis }\end{array}$ & $\begin{array}{l}\text { Ocular } \\
\text { pathology }\end{array}$ & $\begin{array}{l}\text { Ocular } \\
\text { history }\end{array}$ & $\begin{array}{l}\text { Medical } \\
\text { history }\end{array}$ & $\begin{array}{l}\text { Blood picture } \\
\text { and lipoprotein } \\
\text { spectrum }\end{array}$ & $\begin{array}{l}\text { Family } \\
\text { examination }\end{array}$ \\
\hline 1 Ascher $^{1}$ & $39 \mathrm{M}$ & bilateral & $7-8(1 / 3)$ & $\begin{array}{l}\text { anterior } \\
\text { stroma }\end{array}$ & $\begin{array}{l}\text { grey-white, } \\
\text { non-granular }\end{array}$ & $\begin{array}{l}\text { stable for } \\
10 \text { years }\end{array}$ & iritis & recurrent iritis & unremarkable & normal & $\begin{array}{l}\text { two sons } \\
\text { normal }\end{array}$ \\
\hline \multicolumn{12}{|l|}{ Bron $^{2}$} \\
\hline 2 Case 1 & $59 \mathrm{M}$ & bilateral & 10 & $\begin{array}{l}\text { posterior } \\
\text { wedge stroma }\end{array}$ & white & NR & $\begin{array}{l}\text { unilateral, } \\
\text { marginal, } \\
\text { infiltrate }\end{array}$ & unremarkable & NR & normal & $\begin{array}{l}\text { relatives not } \\
\text { available }\end{array}$ \\
\hline 3 Case 2 & $66 \mathrm{~F}$ & bilateral & 8 & $\begin{array}{l}\text { posterior } \\
\text { wedge stroma }\end{array}$ & $\begin{array}{l}\text { white, } \\
\text { granular }\end{array}$ & NR & $\begin{array}{l}\text { unilateral, } \\
\text { marginal, } \\
\text { infiltrate }\end{array}$ & NR & $\begin{array}{l}\text { angina and } \\
\text { coronary } \\
\text { thrombosis }\end{array}$ & NR & NR \\
\hline 4 Rieger $^{3}$ & $65 \mathrm{M}$ & unilateral & $7-8$ & $\begin{array}{l}\text { anterior } \\
2 / 3 \text { stroma }\end{array}$ & $\begin{array}{l}\text { grey-white, } \\
\text { yellow }\end{array}$ & NR & none & unremarkable & unremarkable & $\begin{array}{l}\text { elevated serum } \\
\text { cholesterol }\end{array}$ & NR \\
\hline \multicolumn{12}{|l|}{ Bopp/Laqua ${ }^{4,5}$} \\
\hline 5 Case 1 & $80 \mathrm{~F}$ & bilateral & $7-8$ & $\begin{array}{l}\text { anterior } \\
1 / 2 \text { stroma }\end{array}$ & grey, granular & $\begin{array}{l}\text { stable for } \\
9 \text { years }\end{array}$ & cataract & NR & NR & normal & $\begin{array}{l}\text { relatives } \\
\text { normal }\end{array}$ \\
\hline 6 Case 2 & $65 M$ & bilateral & $4-5(1 / 3)$ & $\begin{array}{l}\text { anterior } \\
2 / 3 \text { stroma }\end{array}$ & grey-white & $\begin{array}{l}\text { stable for } \\
6 \text { years }\end{array}$ & cataract & cataract & NR & normal & $\begin{array}{l}\text { siblings } \\
\text { normal }\end{array}$ \\
\hline 7 Present study & $25 \mathrm{M}$ & bilateral & $8(1 / 3)$ & $\begin{array}{l}\text { anterior } \\
1 / 2 \text { stroma }\end{array}$ & white, granular & $\begin{array}{l}\text { stable for } \\
2 \text { years }\end{array}$ & none & $\begin{array}{l}\text { unilateral } \\
\text { ocular trauma }\end{array}$ & unremarkable & normal & $\begin{array}{l}\text { relatives } \\
\text { normal }\end{array}$ \\
\hline
\end{tabular}

Corneal depositions have been described to originate from three sources-topical or systemic drugs, ocular or systemic metabolic disorders, and corneal dystrophies or degenerations. ${ }^{6}$ Corneal opacities induced by topical or systemic drugs usually involve both the central and peripheral cornea. ${ }^{9}$ To our knowledge, accumulation of a drug in a ring-shaped fashion in the anterior stroma has not been described. In his profession, our patient was exposed for a prolonged period of time to vaporised trichlorethylene, but corneal opacification with systemic use of this drug has not been described. ${ }^{9}$

A wide variety of ocular and systemic disorders have been associated with depositions throughout the cornea. ${ }^{710}$ Ring-shaped opacities limited to the peripheral cornea include subepithelial pigment globules in alkaptonuria, ${ }^{11}$ gold deposition within the peripheral corneal epithelium in ocular chrysiasis, ${ }^{10} 11$ and copper or silver deposition at the level of Descemet's membrane in, respectively, Wilson's disease (Kayser-Fleischer ring) and ocular argyrosis, ${ }^{10}{ }^{11}$ epithelial crystals in Waldenström's macroglobulinaemia, ${ }^{12}$ and peripheral corneal depositions in Scheie syndrome. ${ }^{13}$ A peripheral corneal arcus may result from a deficient lipoprotein metabolism with fat deposition over the entire corneal thickness, and is characterised by a distinct peripheral and an indistinct central border. ${ }^{14}$ In our patient, the ring opacity could be distinguished from a typical arcus by its more granular appearance, involvement of only the anterior stroma, the sharp borders, and the more central location of the ring - that is, a wide band of clear cornea between the opacity and limbus. The serum copper and lipoprotein spectrum were normal, incompletely degraded mucopolysaccharides and homogentisic acid were absent in the urine, and our patients never used gold or silver containing drugs. Therefore, the ring opacity could not be related to known metabolic disorders.

Corneal dystrophies associated with anterior stromal opacities usually show involvement of the central cornea. ${ }^{1016}$ In our patient, the granular deposition was finer and more regularly distributed than in a granular or central crystalline corneal dystrophy, but more distinct than in a central cloudy ${ }^{15} 16$ or macular corneal dystrophy. ${ }^{15} 16$ The overall appearance of the ring opacity did not fit in with any of the known corneal dystrophies. ${ }^{15-17}$

Ring-shaped degenerations of the cornea with advancing age include mosaic crocodile shagreen, Vogt's white limbal girdle, single or double anterior embryotoxon (arcus senilis), and posterior embryotoxon (prominent line of Schwalbe). ${ }^{10}{ }^{16}$ Furrow degeneration in the absence of an arcus senilis, may present as a circumferential, peripheral corneal opacification with an irregular outline. ${ }^{16}$ Early spheroid degeneration may present with gold coloured, peripheral deposits. ${ }^{76}$ In early Terrien's marginal degeneration, peripheral opacification with vascularisation may be found, before corneal ectasia develops. ${ }^{716}$ Iron deposition with a Hudson Stähli or Stocker's line in keratoconus, may have a semicircular configuration and a colourless appearance. ${ }^{10}{ }^{16}$ Semicircular rings in the inferior corneal halves have also been found in aplasia cutis congenita circumscripta. ${ }^{18}$ Central corneal ring opacities with a reddish brown appearance have been described in hereditary spherocytosis. ${ }^{19}$ A Coats' white ring may be observed after local corneal tissue damage by an iron foreign body. ${ }^{16}$ Again, the corneal ring in our patient could be differentiated from all of the peripheral corneal degenerations above, by the perfect round configuration, the fine, colourless granular appearance, the anterior stromal distribution, and the more central location of the opacity.

From our study we conclude that an asymptomatic, mid peripheral corneal ring opacity has been observed in seven healthy, adult patients (Table 1). Except for two cases, the corneal ring manifested bilaterally, as a sharply outlined, grey-white opacity in the anterior stroma. The opacity resulted from a deposition of an unknown material, that showed an acoustic reflectivity similar to corneal tissue with ultrabiomicroscopy, so that deposition of highly reflective substances like, for example, calcium or lipids is unlikely. The distribution of the opacities in a perfect ring - that is, at an equal distance from the corneal centre, may suggest that the material was deposited after diffusion over a gradient between the peripheral and central cornea or vice versa. The occurrence of the corneal ring at a young adult age may suggest that the deposition resulted 
from a corneal dystrophy rather than a degeneration, although no evidence of an inherited disorder was found in our patient or in any of the cases described (Table 1). ${ }^{1-5}$ Like others, we found that the opacity showed no detectable progression, which may suggest that the ring resulted from exposition to an exogenous or endogenous factor for a limited period of time-for example, a drug to which an idiosyncratic reaction developed.

We thank A L Aandekerk for the slit lamp photography, and A M Verbeek for performing ultrasound biomicroscopy.

1 Ascher KW. Ungewöhnliche Hornhautringe. Ber Dtsch Ophthal Ges 1963;65:44-6.

2 Bron AJ. Peripheral ring opacity of the cornea. $\mathrm{Br} f$ Ophthalmol 1969;53:270-3.

3 Rieger G. Primäre, einseitige, ringförmige Trübung der Hornhaut. Fortschr Ophthalmol 1987;84:242-4.

4 Laqua H. Parazentrale ringförmige Hornhauttrübung. Ber Dtsch Ophthal Ges 1971;71:583-5.

5 Bopp S, Laqua H. Kornealer Ascher-Ring. Klin Monatsbl Augenheilkd 1991;198:201-4.

6 Waring GO, Rodrigues MM. Patterns of pathologic response in the cornea. Surv Ophthalmol 1987;31:262-6. response in the cornea. Surv Ophthalmol 1987;31:262-6. Robin JB, Schanzlin DJ, Verity SM, et al. Perp
disorders. Surv Ophthalmol 1986;31:1-36.

8 Mondino DJ. Inflammatory diseases of the peripheral cornea. Ophthalmology 1988;95:463-72

Fraunfelder FT, Meyer SM. Ocular toxicology. In: Tasman W, Jaeger EA, eds. Duane's clinical ophthalmology. Volume 5,
Chapter 37, revised edition. Philadelphia: LippincottRaven, 1990:1-21.

10 Vogt A. Die normale Hornhaut, ihre senilen und pathologischen Veränderungen. In:Lehrbuch und Atlas der Spaltlampenmikroskopie des lebenden Auges. Berlin: Springer, 1930: 47-269.

11 Smith RE, Lee IS. The cornea in systemic disease. In: Tasman W, Jaeger EA, eds. Duane's clinical ophthalmology. Volume 4, Chapter 15, revised edition. Philadelphia: Volume 4, Chapter 15, revised
Lippincott-Raven, 1990:1-44.

12 Orellana J, Friedman AH. Dysproteinemias. In: Gold DH, Weingeist TA, eds. The eye in systemic disease. Philadelphia: Lippincott, 1990:134-7.

13 Bajart AM, Pavilack MA. Corneal manifestations of metabolic disease. In: Albert DM, Jackobiec FA, eds. Principles and practice of ophthalmology. Philadelphia: Saunders, 1994:294-319.

14 Barchiesi BJ, Eckel RH, Ellis PP. The cornea and disorders of lipid metabolism. Surv Ophthalmol 1991;36:1-22.

15 Waring GO, Rodrigues MM, Laibson PR. Corneal dystrophies. I Dystrophies of the epithelium, Bowman's layer and stroma. Surv Ophthalmol 1978;23:71-122.

16 Kenyon KR, Hersh PS, Starck T, et al. Corneal dysgeneses, dystrophies and degenerations. In: Tasman W, Jaeger EA, eds. Duane's clinical ophthalmology. Volume 4, Chapter 16, revised edition. Philadelphia: Lippincott-Raven, 1992:153.

17 Bron AJ, Williams HP, Carruthers ME. Hereditary crystalline stromal dystrophy of Schnyder. I Clinical features of a family with hyperlipoporoteinaemia. $\mathrm{Br} f$ Ophthalmol 1972; 56:383-99.

18 Vogel M, Kiessling W. Weisse Hornhautringe in Verbindung mit aplasia cutis congenita circumscripta des behaarten Kopfes. Ber Dtsch Ophthal Ges 1964;66:361-4.

19 Dalgleish R. Ring-like corneal deposits in a case of congenital spherocytosis. Br F Ophthalmol 1965;49:40-2. 